\title{
Impact of Rationing on The Properties of Cement-Treated Gypsum Canals
}

\author{
Wissam S. Al-Jassim ${ }^{1}$, Maysam Th. Al-Hadidi ${ }^{2}$ \\ l'Department of water resources engineering, University of Baghdad, Baghdad, Iraq, wissamiraq2000@yahoo.com \\ ${ }^{2}$ Department of water resources engineering, University of Baghdad, Baghdad, Iraq, mays.thamer@coeng.uobaghdad.edu.iq \\ *Corresponding author: Wissam S. Al-Jassim, wissamiraq2000@yahoo.com
}

Published online: 30 September 2020

Abstract- The scarcity of irrigation water requires procedures of specific. One of these procedures is the implementation of the rationing system (a period of the irrigation followed by a period of the dry). This system can have an impact on the properties of irrigation channels. Therefore, the study of rationing system for irrigation channels is important in both water resources and civil engineering, especially if they are constructed with gypseous soil. In order to assess the rationing system on gypseous canals stabilized with a specific ratio of cement, practical experiments were conducted to detect the effect of wetting and drying cycles on the physical and hydraulic behavior of this soil and calculation of some properties of soil such as scouring, grain size and gypsum content of soil at each cycle (10 days wetting and 10 days of drying). Where the gypseous soil with gypsum content $65 \%$ was brought from Lake Sawh-Iraq to the hydraulic laboratory at the University of Baghdad, Physical and chemical tests were carried out according to the standard classification system. The laboratory work includes construction of a laboratory flume with gypseous soil to calculate the scouring of the canal and effect grain size of soil by two methods (the standard sieve analysis and Particle size absorptive test) and also calculate gypsum content at each rationing cycle, where the channel consists of two stages of operation, the one for untreated soil (4 cycles operation) and the other for soil mixed with $10 \%$ cement $(5 \mathrm{~cm}$ of cement mixture above $5 \mathrm{~cm}$ soil) 4 cycles also. The results show that the rationing cycles reduce the scouring of canal in the case of untreated soil by $56.6 \%$ and in the case of treated soil $82 \%$. The rationing system led to course the gradient of soil according to two methods. Also its reduction of the gypsum content in the case of untreated soil by $43 \%$ and in the case of treated soil $45.6 \%$. Thus, conclude that the rationing system leads to a positive effect on some properties of gypsum soils and the lining of irrigation channels.

Keywords- Rationing System, Drying and Wetting, Gypsum Soil, Irrigation Canals and Scouring.

\section{Introduction}

The limited water resources have led to alternative ways of managing water and economizing on water consumption and distribution, one of them is the application of the rationing system, which causes soil exposure to systematic changes in moisture and drought in the surface of the irrigation channels, so the properties of the soil may change according to these changes. And to know the impact of these changes are studied laboratory properties of soil exposed to conditions are similar to those in the field as wetting and drying cycles. Study the effect of these conditions in the physical, hydraulic and engineering properties is important because sometimes they affect the lining of the irrigation channels. Gypseous soil is the soil which contains amounts of gypsum, one of the mineral salts known as calcium sulfate, which that a chemical formula $(\mathrm{CaSO} 4.2 \mathrm{H} 2 \mathrm{O})$ and the specific gravity is low about is 2.32 that affect significant on the physical and mechanical properties of soil that contains high amounts of gypsum [1]. Gypseous soils are existing across the world, especially in the Middle East, the Gulf and Red Sea region $[9,12]$. Its cover about $28.6 \%$ of the total land area in Iraq, equivalent to cover nearly $8.7 \%$ of gypseous soil in the world [10]. It represents the most problems that challenge Geotechnics and engineers. So, it's necessary to study and improve most of its properties due to the failure of the structures, for this reason they focused on soil behavior through wetting because of the gypsum dissolution in the soil [4]. Al-Zubaydi et.al. Studied the effect of weather condition different of the structures, indicate that the passing of water through soil causes devastation of soil, leading to increase in permeability, collapse, swelling and settlement [5]. In addition, the study by Razouki and Salem was seemed to be the first study, which dealing with wetting and drying of gypseous soils, their study includes (3 months) of wetting followed by (3 months) of drying [13]. There are of many treatments for gypseous soils, as physical, mechanical, 
and chemical treatments. These treatments increase the soil durability, where the infiltration decreases under structures and irrigation canals; therefore, it increases the efficiency of the irrigation canals. The most widespread solution to decrease the scouring and infiltration is lining canals [11]. Stabilization of Cement is one of economical techniques for improving the properties of gypseous soils. So the main objective of this study is to analyze performance of the cement by studying of properties of gypseous soils such as scouring, grain size and gypsum content under the influence several times of rationing. In order to compare the results, a single percentage of cement material which is the best treatment percentage used $10 \%$ by weight [2].

\section{Experimental outlines:}

\subsection{The laboratory Flume}

The laboratory flume, used in this study to obtain and extract the results. It is an open channel with English brand, made from steel stiffeners and glass fiber, which has $10 \mathrm{~m}$ total length, $0.3 \mathrm{~m}$ width and $0.35 \mathrm{~m}$ depth. Generally, the laboratory flume is divided into three parts; the first part is a water storage and pumping system. The second part of the laboratory flume represents the most important part of the flame is called the working section. The last part of the laboratory flume is a reservoir which collects water coming from the working section. A point gauge has been used to measure both soil scouring and water depths with an accuracy of $( \pm 1) \mathrm{mm}$. Figure 1 shown laboratory flume used in this study.

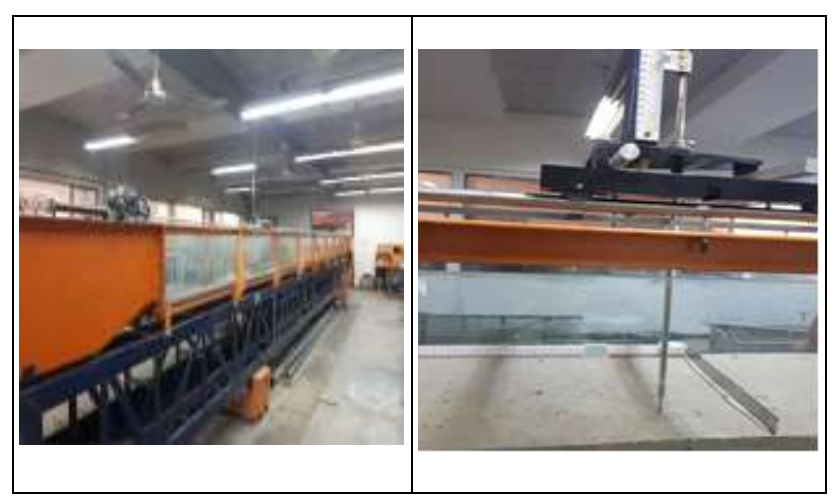

Figure 1: The laboratory flume and some parts it

\subsection{Materials}

\subsubsection{Soil}

The gypseous soils have been used in this study. It was brought from the region of Lake Sawa, which is located in the western part of Al-Muthanna Governorate $(280 \mathrm{~km}$ south of Baghdad-Iraq). At the beginning of the work, the region was surveyed and different samples were taken from specific sites by a GPS device, the ratio of gypsum in these samples was examined. After that the soil took the one type of soils collected from a depth of (1.5-2 m) and transported to the hydraulics laboratory of the College of Engineering at University of Baghdad for testing. The total weight of the soil used in these experiments was $1350 \mathrm{~kg}$ with high gypsum content is $65.4 \%$.

\subsubsection{Cement}

Cement is the primary material which used to treat the gypseous soil in these experiments; the cement used is of salt-resistant Portland cement.

\subsubsection{Water}

In this work, the tap water was used in all tests.

\subsection{Experimental Work and Testing Program}

The flow chart of all tests performed in this study as shown in Figure 2, the testing program is divided into two parts. The first part is performed on gypseous soil at natural state and cement material which including tests of soil classification (physical tests, chemical tests and mechanical tests) and also test of X-ray diffraction for cement material. Second part of the testing program is the experiments which conducted on the laboratory flume, including the scouring, grain size distribution and gypsum content. These tests can be summarized as follows:

\subsubsection{Physical tests}

Physical tests are carried out on the gypseous soil, these tests included:

\subsubsection{Specific Gravity Test (GS)}

The specific gravity of the natural soil is determined in accordance with the standards of British (BS 1377: 1990, Test 6B, Head 2004) [16], the kerosene is used instead of water to avoid the dissolution of the gypsum in water during the test.

\subsubsection{The particle size distribution}

In this study, the particle size distribution of the soil is found by following two methods:

\subsection{Grain size distribution}

The standard sieve analysis test is carried out to determine the grain size distribution in accordance with standard ASTM test (ASTM D422; 2002) [6], dry sieving. The result is shown in Figure A-1(Appendix A). 


\subsection{Particle size absorptive test (laser diffraction)}

The particle size absorptive of the soil samples was conducted at the laboratories of the Iraqi Geological Survey; it was carried out by technique laser diffraction as shown in figure 3, the data were obtained using software (Mastersizer 2000, Ver. 5.60 from Malvern) Scirocco 2000 dry [14]. The data were expressed as $\mathrm{D}_{0.1}$, $\mathrm{D}_{0.5}$ and $\mathrm{D}_{0.9}$ which are equivalent size diameters at $10 \%$, $50 \%$ and $90 \%$ cumulative volume, respectively. Figure 3 shows Mastersizer 2000, Ver. 5.60.

\subsubsection{Water content}

The water content is performed in according to (BS 1377: 1990, Test A, Head 2004)[16]; by drying the soil at $\left(45^{\circ} \mathrm{C}\right)$ because the soil has a high ratio of gypsum.

\subsubsection{Chemical Tests}

Chemical tests are carried out on the soil and cement material, these tests included:

\subsubsection{Gypsum content}

In this study, the gypsum content is found by two methods:

\subsection{Hydration Method}

The gypsum content shall be determined in the Hydration Method, which executed by Al Mufty and Nashat [3]. Its include of drying a soil sample by an oven at a temperature of $45^{\circ} \mathrm{C}$ until the weight of the sample is fixed and recorded this weight at $45^{\circ} \mathrm{C}$. The same sample is drying at a temperature of $110^{\circ} \mathrm{C}$ for 24 hours and recorded that weight again; Equation (1) is used to calculate the gypsum content.

$\chi \%=\frac{w 45^{\circ} \mathrm{C}-w 110^{\circ} \mathrm{C}}{w 45^{\circ} \mathrm{C}} \times 4.778 \times 100$

\subsection{Concentration of Sulfate Method}

The Concentration of sulfate method used to determine gypsum content according to the British standards (BS 1377:1975)[8] as in the Equation (2).

$\chi \%=\mathrm{SO}^{3} \times 2.15$

\subsubsection{X-ray Fluorescence spectrometer test}

X-ray fluorescence method is the most widely used to determine of minerals and the study of crystal structure of those minerals. The Iraqi-German Laboratory at the College of Geosciences at the University of Baghdad conducted this test. From the result of the X-ray fluorescence test for cement, it is found that the cement is resistant to sulfates according to (the standard Iraqi no. 5 for cement Portland 1984) [15], as it is characterized by low Alumina Modulus as well as a value of the Lime Saturation Factor. See Table 1.
Table 1: Summary of the results of the X-ray tests and limits specified for the compounds of Portland cement by standard Iraqi No. 5 (1984)

\begin{tabular}{|c|c|c|}
\hline Properties & $\begin{array}{c}\text { The result of the } \\
\text { X-ray fluorescence }\end{array}$ & $\begin{array}{c}\text { The limits specified } \\
\text { according to the } \\
\text { standard Iraqi no. 5 } \\
(1984)\end{array}$ \\
\hline $\mathrm{Fe}_{2} \mathrm{O}_{3}$ & 5.504 & $2-4$ \\
\hline $\mathrm{Al}_{2} \mathrm{O}_{3}$ & 2.576 & $4-8$ \\
\hline $\mathrm{SiO}_{2}$ & 19.16 & $18-24$ \\
\hline $\mathrm{CaO}$ & 68.62 & $60-69$ \\
\hline $\mathrm{SO}$ & 2.967 & $0.3-2.7$ \\
\hline $\mathrm{MgO}$ & 1.943 & $2-5$ \\
\hline $\mathrm{S} . \mathrm{M}$ & 0.46 & $1.9-3.2$ \\
\hline $\mathrm{A} . \mathrm{M}$ & 2.24 & $1.5-2.5$ \\
\hline $\mathrm{L} . \mathrm{S} . \mathrm{F}$ & 1.017 & $1.02-0.66$ \\
\hline
\end{tabular}

\subsubsection{Mechanical Tests}

Mechanical tests are executed on the soil, included compaction test only.

\section{- Compaction test}

The standard compaction test is performed for the natural soil to determine the density-moisture relationship. It's carried out accordance with (ASTM D698-91, Method A, 2003) [7]. The result of compaction test is shown in Figure 4. Table 2 represents the physical, chemical and mechanical properties of soil, which were in accordance with ASTM specifications.

Table 2: Summary of the physical and chemical tests for natural soil

\begin{tabular}{|c|c|}
\hline Properties & Value \\
\hline Gypsum Content (\%) & $65 \%$ \\
\hline Max. dry unit weight, $\gamma_{\max }$ & $16.8\left(\mathrm{kn} / \mathrm{m}^{3}\right)$ \\
\hline Optimum Water Content (\%) & 11.8 \\
\hline Specific Gravity, (Gs) & 2.37 \\
\hline Void ratio, (e) & 0.411 \\
\hline Porosity, (n) & 0.29 \\
\hline $\mathrm{D}_{10}$ & $0.05 \mathrm{~mm}$ \\
\hline $\mathrm{D}_{60}$ & $0.6 \mathrm{~mm}$ \\
\hline $\mathrm{D}_{30}$ & $0.16 \mathrm{~mm}$ \\
\hline
\end{tabular}




\begin{tabular}{|c|c|}
\hline Coefficient of curvature, $\mathrm{Cc}$ & 12 \\
\hline Coefficient of uniformity, $\mathrm{Cu}$ & 0.85 \\
\hline Soil Classification (USCS) & Gypsum soil (SP) \\
\hline
\end{tabular}

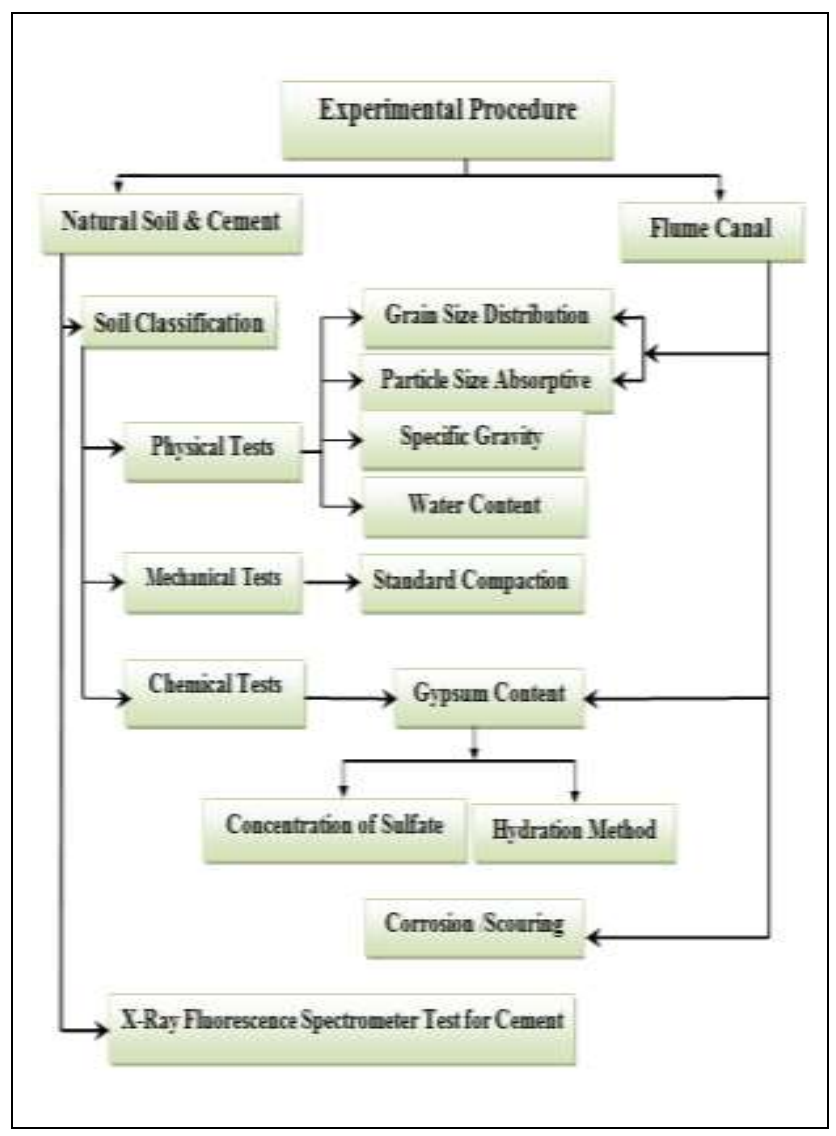

Figure 2: Flowchart of testing program.

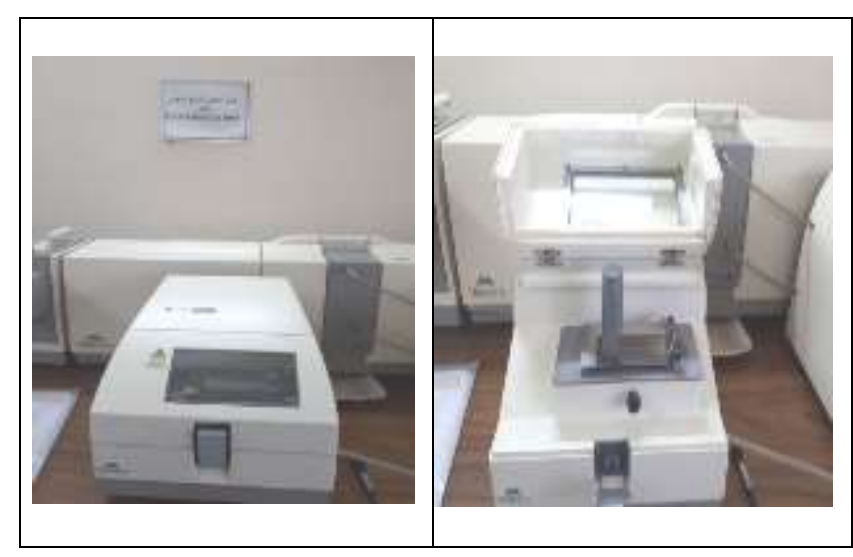

Figure 3: Mastersizer 2000, Ver. 5.60 from Malvern, use to determined particle size distribution

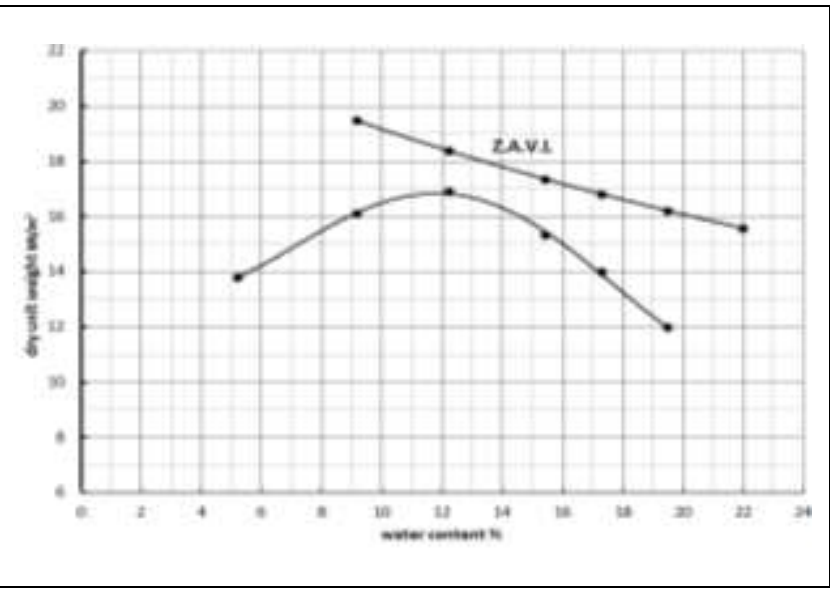

Figure 4: Standard compaction test of the natural soil

\section{Preparation of Soil and Test Procedure}

Soil models are prepared at a moisture content equal to the optimum water content in accordance with (ASTM D698; 2003)[7], and models of soil are mixed careful with the specified amount of water until the soil reaches to the optimum moisture content. In this study, the test Procedure consists of two stages: the first stage of untreated gypsum soil (one models) and the second stage of the soil treated with cement (one models).

The first stage was with untreated of gypsum soil. One model of the untreated gypsum soil in the laboratory flume is constructed for thickness of $10 \mathrm{~cm}$ and compacted by maximum dry unit weight $\left(16.8 \mathrm{kN} / \mathrm{m}^{3}\right)$ and optimum moisture content (11.8\% by weight), using a compactor and point gage to obtain a good compaction and accurate in soil in thickness of $10 \mathrm{~cm}$, the flow characteristics of first stage shown in Table 3.

The second stage was with the treatment of gypsum soil. One model of treatment gypsum soil is mixed with a percentage of (10\% weight cement) [2], this mixture is prepared in $5 \mathrm{~cm}$ thickness and compacted at a maximum dry density $\left(16.8 \mathrm{kN} / \mathrm{m}^{3}\right)$ and optimum moisture content $(11.8 \%)$. Where, total soil thickness in the laboratory flume is $10 \mathrm{~cm}$, the duration maturation of the cement mixture is 14 days, see Figure 5, the flow characteristics of second stage shown in Table 4. The laboratory flume was set on a slope of 0.002 and operated with flow characteristics of water. Where, discharge, velocity and water depth are $\left(0.00637 \mathrm{~m}^{3} / \mathrm{sec}, 0.212 \mathrm{~m} / \mathrm{sec}\right.$ and $\left.0.1 \mathrm{~m}\right)$ respectively, are fixed for all cycles. The water flows in the channel for 10 days, it is called the cycle of wetting, after ending of the wetting period, begins drying cycle, where the channel is left in the air atmosphere for 10 days also. After that, a series of measurements are taken after drying period which includes:

1-Elevations measurement of the soil surface by using the point gage device in three dimensions $(\mathrm{x}, \mathrm{y}$ and $\mathrm{z})$ the distance between the points in $(\mathrm{x})$ direction was $(7 \mathrm{~cm})$ and in $(\mathrm{y})$ direction was $(10 \mathrm{~cm})$. Where the total number 
of points carried out were 255 points (elevations) on the soil surface for each cycle as shown in Figure 6.

2- Grain size distribution and particle size absorptive test. After the drying period, we take the sample from the surface of the soil for the purpose of conducting the tests for soil gradation for each cycle.

3- Calculate the gypsum content at the end each cycle.

Table 3: The flow characteristics of laboratory flume for first stage at $16 \mathrm{C}^{0}$ Temp.

\begin{tabular}{|c|c|c|c|c|c|c|c|c|}
\hline $\mathrm{S}$ & $\mathrm{H}$ & $\mathrm{W}$ & $\mathrm{R}$ & $\begin{array}{c}\mathrm{Q} \\
m^{3} / s e \\
c\end{array}$ & $\mathrm{~V}$ & $\mathrm{~m} / \mathrm{sec}$ & $\mathrm{Re}$ & $\mathrm{We}$ \\
\hline 0.002 & 0.1 & 0.3 & 0.06 & 0.006 & 0.212 & 0.214 & 1943 & 62 \\
\hline
\end{tabular}

Table 4: The flow characteristics of laboratory flume for second stage at $29 \mathrm{C}^{0}$ Temp.

\begin{tabular}{|c|c|c|c|c|c|c|c|c|}
\hline $\mathrm{S}$ & $\begin{array}{c}\mathrm{H} \\
(m)\end{array}$ & $\begin{array}{c}\mathrm{W} \\
(m)\end{array}$ & $\begin{array}{c}\mathrm{R} \\
(m)\end{array}$ & $\begin{array}{c}\mathrm{Q} \\
m^{3} / s e c\end{array}$ & $\begin{array}{c}\mathrm{V} \\
m / s e c\end{array}$ & $\mathrm{Fr}$ & $\mathrm{Re}$ & $\mathrm{We}$ \\
\hline 0.002 & 0.1 & 0.3 & 0.06 & 0.006 & 0.212 & 0.214 & 2636 & 61 \\
\hline
\end{tabular}

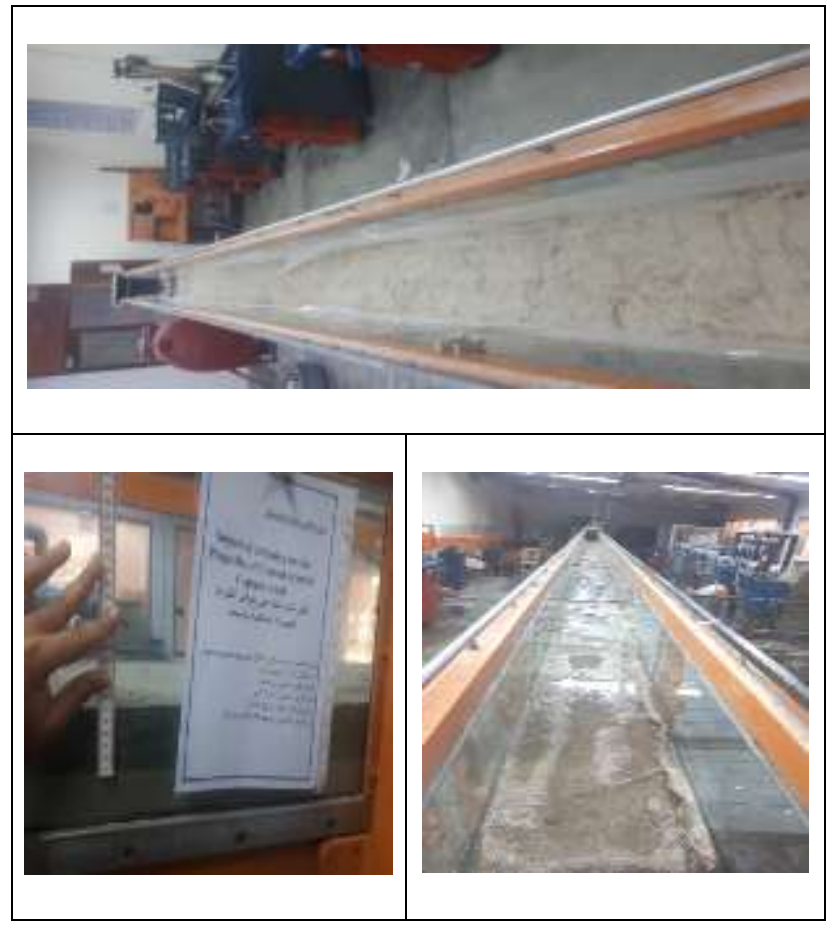

Figure 5: Preparation of laboratory flume

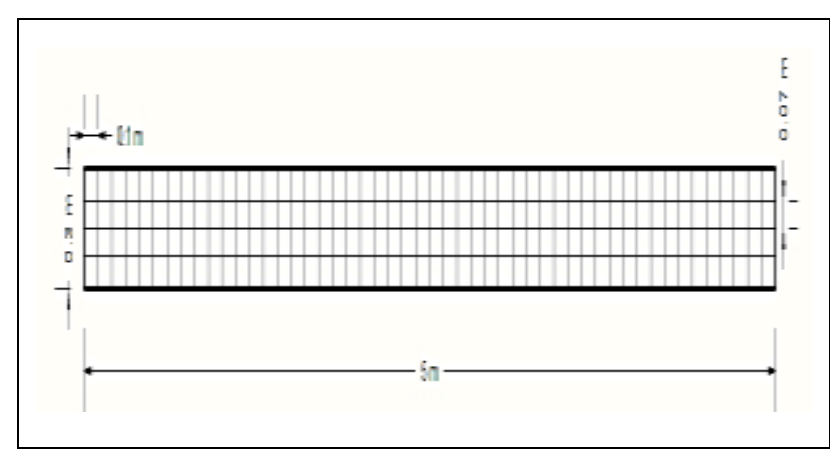

Figure 6: The points on the surface soil of the canal, whose readings were taken

\section{Results and Discussions}

\subsection{Effect of rationing on the scouring of soil}

Contour maps illustrate the elevation of the soil points. In this study, (SURFER V 13) software used to draw contour maps for showing the scouring for both untreated and treated Soil at each cycle of the rationing system. The results of untreated gypsum soil scouring at each rationing cycle as shown in Figure 7. It was observed that, there is a simple scouring in the first half of the canal during the first cycle and begins to increase at the subsequent cycles.

The results of treated soil scouring at each rationing cycle as shown in Figure 8. It was observed that, there was a small rate of scouring at first cycle and the change rate of elevation was about constant during the subsequent cycles. Through comparison with the results of previous studies conducted by Al-Hadidi and AL-Maamori [2], on the same laboratory fume and the same percentage of cement, which is $10 \%$, notice that the rationing cycles, reduce the scouring of canal in the case of untreated soil by $56.6 \%$ and in the case of treated soil $82 \%$.The summary of results for untreated and treated soil scouring at each rationing cycle as shown in Table $\mathbf{5}$.

From the results of scouring for treated soil, in the case rationing system, it is possible to estimate the scour lined of channels. And also, the period required for periodic maintenance of these lined channels, where maximum corrosion is $0.05 \mathrm{~cm}$ every 20 days. Drawing points between corrosion and time, where concludes that relationship with high accuracy presented in Figure A-2 (Appendix A), and described by Equation (3).

$Y=-0.0071 X^{2}+0.9438 X+0.1443$ 


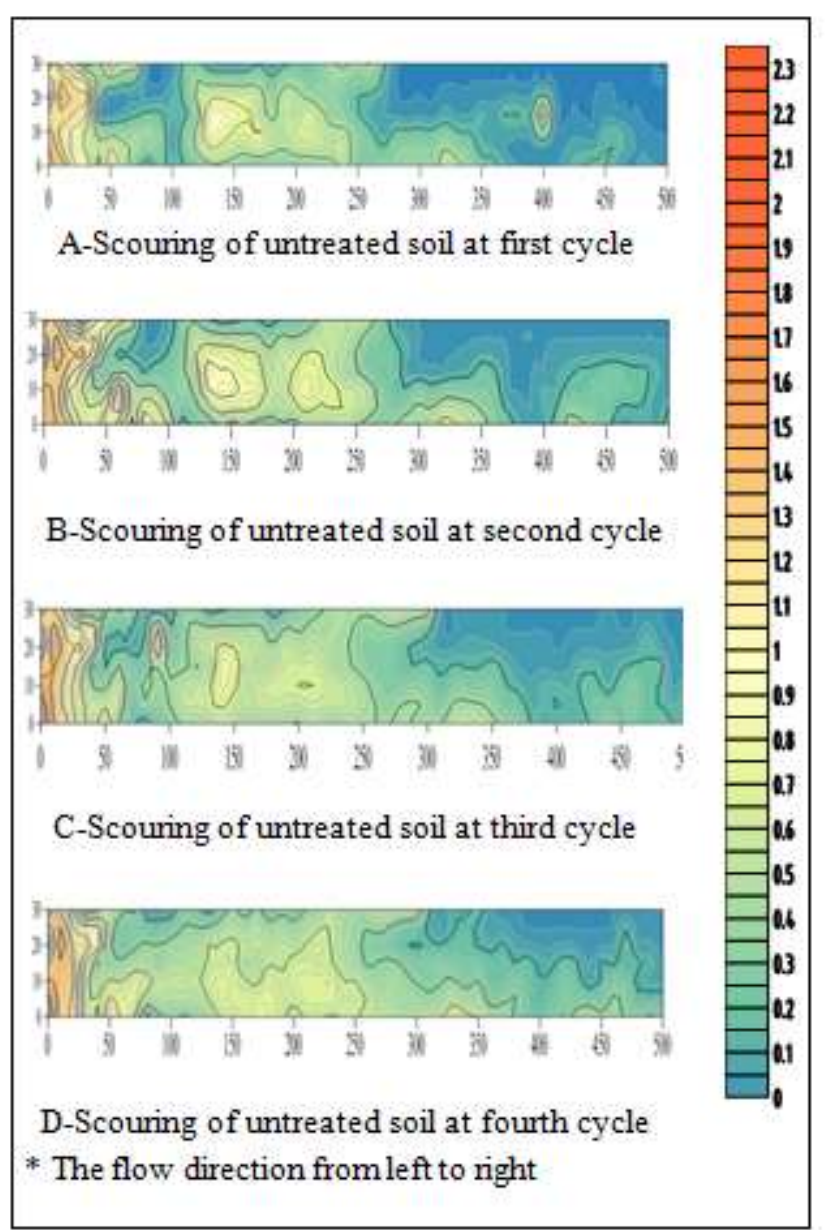

Figure 7: Contour maps of the scouring in the untreated gypsum soil.

\subsection{Effect of rationing on the particle size of the untreated soil}

Table 6 and Table 7 are the results of the particle size distribution tests for four cycles were conducted using sieve analysis test and particle size absorptive test (Mastersizer 2000, Ver. 5.60 from Malvern) respectively. Figure A-7 (Appendix A) is shown an effect rationing in particle size for four cycles, it is clearly noticed that rationing system yields coarse gradation. This may be interpreted by the dissolution of fine gypsum particles by wetting and drying.

The results of particle size absorptive by Mastersizer 2000were placed in Figures A-3, A-4, A-5 and A-6 (Appendix A) for the end for the end first, second, third and fourth cycle, respectively

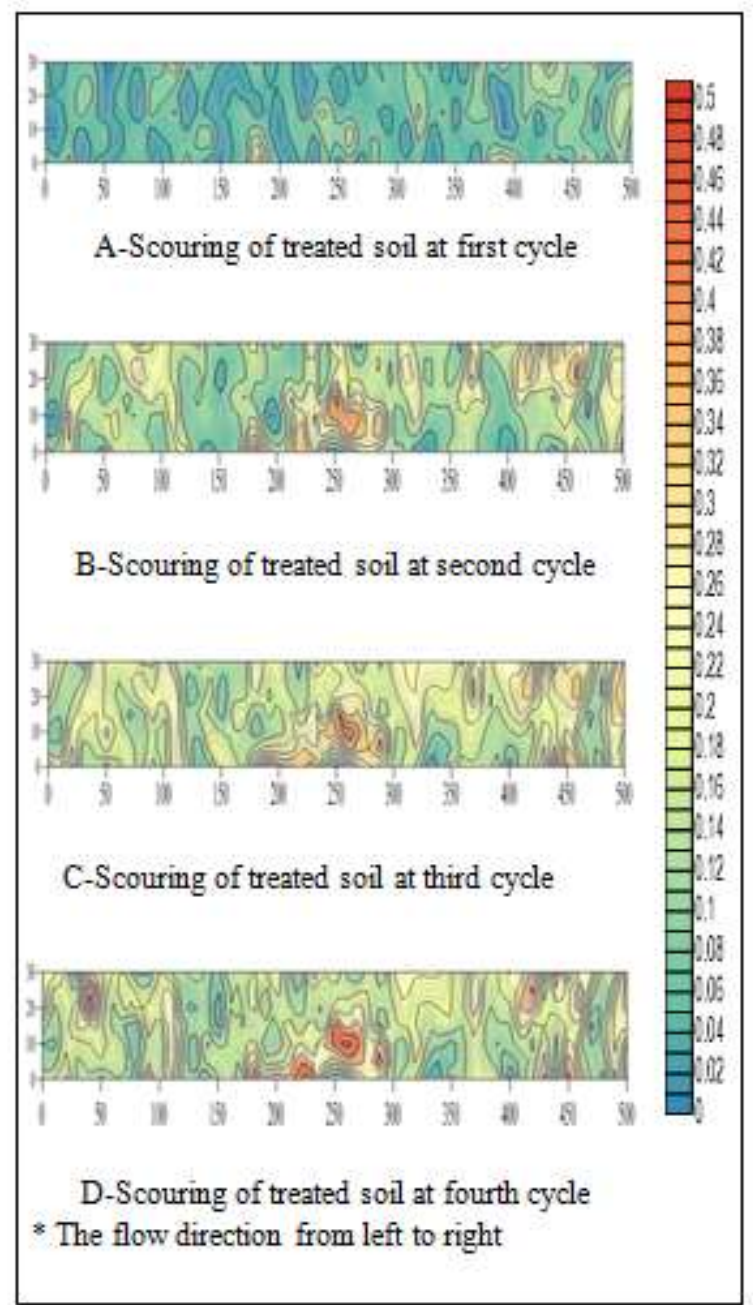

Figure 8: Contour maps of the scouring in the treated gypsum soil.

Table 5: Summary of results for untreated and treated soil scouring at each rationing cycle

\begin{tabular}{|c|c|c|c|c|}
\hline \multirow{2}{*}{$\begin{array}{l}\text { No. of } \\
\text { cycle }\end{array}$} & \multicolumn{2}{|c|}{ Untreated soil } & \multicolumn{2}{|c|}{ Treated soil } \\
\hline & $\begin{array}{c}\text { Max.scour } \\
(\mathrm{cm})\end{array}$ & $\begin{array}{c}\text { Av.scour } \\
(\mathrm{cm})\end{array}$ & $\begin{array}{c}\text { Max.scour } \\
(\mathrm{cm})\end{array}$ & $\begin{array}{c}\text { Av.scour } \\
(\mathrm{cm})\end{array}$ \\
\hline 1 & 1.5 & 1.41 & 0.25 & 0.063 \\
\hline 2 & 1.8 & 1.55 & 0.4 & 0.103 \\
\hline 3 & 1.95 & 1.78 & 0.45 & 0.151 \\
\hline 4 & 2.25 & 2.1 & 0.5 & 0.193 \\
\hline
\end{tabular}


Table 6: Summary of D-Values detail $\left(\mathrm{D}_{10}, \mathrm{D}_{50} \& \mathrm{D}_{90}\right)$ by sieve analysis test

\begin{tabular}{|c|c|c|c|}
\hline $\begin{array}{c}\text { No. of } \\
\text { cycle }\end{array}$ & $\begin{array}{c}\mathrm{D}_{10} \\
(m)\end{array}$ & $\begin{array}{c}\mathrm{D}_{50} \\
(m)\end{array}$ & $\begin{array}{c}\mathrm{D}_{90} \\
(m)\end{array}$ \\
\hline 1 & 0.000052 & 0.00040 & 0.0027 \\
\hline 2 & 0.000065 & 0.00045 & 0.0025 \\
\hline 3 & 0.00022 & 0.0006 & 0.0030 \\
\hline 4 & 0.00042 & 0.0011 & 0.0035 \\
\hline
\end{tabular}

Table 7: Summary of D-Values detail (D0.1, D0.5 \& D0.9) by Mastersizer 2000

\begin{tabular}{|c|c|c|c|c|c|}
\hline $\begin{array}{c}\text { No. } \\
\text { cycle }\end{array}$ & $\begin{array}{c}\mathrm{D}_{0.1} \\
(\mu \mathrm{m})\end{array}$ & $\begin{array}{c}\mathrm{D}_{0.5} \\
(\mu \mathrm{m})\end{array}$ & $\begin{array}{c}\mathrm{D}_{0.9} \\
(\mu \mathrm{m})\end{array}$ & $\begin{array}{c}\text { Specific } \\
\text { surface } \\
\text { area }\left(\mathrm{m}^{2} / g\right)\end{array}$ & $\begin{array}{c}\text { Surface } \\
\text { weight } \\
\text { Mean }(\mu \mathrm{m})\end{array}$ \\
\hline 1 & 11.100 & 54.879 & 385.354 & 0.272 & 22.087 \\
\hline 2 & 10.687 & 62.092 & 377.344 & 0.285 & 21.019 \\
\hline 3 & 11.974 & 69.945 & 484.704 & 0.248 & 24.167 \\
\hline 4 & 12.879 & 77.217 & 503.241 & 0.23 & 26.094 \\
\hline
\end{tabular}

\subsection{Effect of rationing on the gypsum content of the gypseous canals}

During four cycles of rationing (80 days), the change in gypsum content is observed during these cycles as shown in Table 8 and Figure A-8 (Appendix A).

From Table 8, in the case of untreated gypsum soils during 80 days, notice that the rationing system reduces gypsum solubility in soil by $(43 \%)$. In the case of treated gypsum soils during the 80 days, the rationing system reduces gypsum solubility in soil by $(45.6 \%)$.
Table 8: Summary of gypsum content reduction under the effect several cases.

\begin{tabular}{|c|c|c|c|c|c|}
\hline Number of cycles & $\begin{array}{l}\text { Befor } \\
\text { e use }\end{array}$ & $\begin{array}{c}1^{\text {st }} \\
\text { cycle }\end{array}$ & $\begin{array}{l}2^{\text {nd }} \\
\text { cycle }\end{array}$ & $\begin{array}{c}3^{\text {rd }} \\
\text { cycle }\end{array}$ & $\begin{array}{c}4^{\text {th }} \\
\text { cycle }\end{array}$ \\
\hline Time (day) & 0 & 20 & 40 & 60 & 80 \\
\hline $\begin{array}{l}\text { Gypsum content for } \\
\text { untreated soil with } \\
\text { rationing }(\%)\end{array}$ & $\begin{array}{c}65.35 \\
3\end{array}$ & $\begin{array}{c}64.76 \\
4\end{array}$ & $\begin{array}{c}63.83 \\
6\end{array}$ & $\begin{array}{c}63.31 \\
1\end{array}$ & 62.459 \\
\hline $\begin{array}{l}\text { Reduction Gypsum } \\
\text { content for untreated } \\
\text { soil with rationing } \\
(\%)\end{array}$ & 0 & 0.900 & 2.002 & 3.123 & 4.427 \\
\hline $\begin{array}{l}\text { Gypsum content for } \\
\text { untreated soil without } \\
\text { rationing }(\%)\end{array}$ & $\begin{array}{c}65.35 \\
3\end{array}$ & $\begin{array}{c}64.25 \\
4\end{array}$ & $\begin{array}{c}63.11 \\
5\end{array}$ & $\begin{array}{c}61.83 \\
1\end{array}$ & 60.285 \\
\hline $\begin{array}{l}\text { Reduction Gypsum } \\
\text { content for untreated } \\
\text { without rationing }(\%)\end{array}$ & 0 & 1.680 & 3.423 & 5.388 & 7.753 \\
\hline $\begin{array}{l}\text { Gypsum content for } \\
\text { treated with rationing }\end{array}$ & $\begin{array}{c}65.35 \\
3\end{array}$ & $\begin{array}{c}65.33 \\
7\end{array}$ & $\begin{array}{c}65.27 \\
8\end{array}$ & $\begin{array}{c}65.24 \\
9\end{array}$ & 65.193 \\
\hline $\begin{array}{l}\text { Reduction Gypsum } \\
\text { content for treated } \\
\text { with rationing }(\%)\end{array}$ & 0 & $\begin{array}{c}0.023 \\
3\end{array}$ & 0.113 & 0.158 & 0.243 \\
\hline $\begin{array}{l}\text { Gypsum content for } \\
\text { treated soil without } \\
\text { rationing }(\%)\end{array}$ & $\begin{array}{c}65.35 \\
3\end{array}$ & $\begin{array}{c}65.31 \\
0\end{array}$ & $\begin{array}{c}65.29 \\
2\end{array}$ & $\begin{array}{c}65.18 \\
9\end{array}$ & 65.059 \\
\hline $\begin{array}{c}\text { Reduction Gypsum } \\
\text { content for treated } \\
\text { without rationing }(\%)\end{array}$ & 0 & $\begin{array}{c}0.065 \\
2\end{array}$ & 0.092 & 0.249 & 0.448 \\
\hline
\end{tabular}

\section{Conclusions}

In this work, two cases with soil gypsum are studied for dealing by scouring canal, grain size and gypsum content. From the analysis of the tests on soil samples and the results of the laboratory flume, the following conclusions can be made:

- The rationing system reduces channel erosion and gypsum solubility in soil compared to channels that operate without this system. Thus, it can be said that the system of rationing gives a longer age to the material lining of irrigation channels.

- In case lining canals, the maximum corrosion of surface canal was increasing $0.05 \mathrm{~cm}$ at every cycle. Thus, it can be estimated age for the material lining of irrigation channels.

- The rationing system yields coarse gradation for surface of canals. 
- The rationing system leads to a positive effect on some properties of gypseous soils and the lining of irrigation channels.

\section{Recommendations}

The study of the impact of rationing on other properties such as channel roughness coefficients because it's a very important factor in the study of open channel flow as well as the study of internal cracks in the lining.

\section{Nomenclature}

\begin{tabular}{|c|c|}
\hline Symbol & Description \\
\hline AM & Alumina Modulus \\
\hline $\mathbf{D}_{0.1}$ & $\begin{array}{l}\text { Diameter size at } 10 \% \text { of cumulative volume } \\
(\mu \mathrm{m})\end{array}$ \\
\hline $\mathbf{D}_{0.5}$ & $\begin{array}{l}\text { Diameter size at } 50 \% \text { of cumulative volume } \\
(\mu \mathrm{m})\end{array}$ \\
\hline $\mathbf{D}_{0.9}$ & $\begin{array}{l}\text { Diameter size at } 90 \% \text { of cumulative volume } \\
(\mu \mathrm{m})\end{array}$ \\
\hline $\mathbf{D}_{10}$ & $\begin{array}{l}\text { Diameter through which } 10 \% \text { of the total } \\
\text { soil mass is passing }(\mathrm{mm})\end{array}$ \\
\hline $\mathbf{D}_{30}$ & $\begin{array}{l}\text { Diameter through which } 30 \% \text { of the total } \\
\text { soil mass is passing }(\mathrm{mm})\end{array}$ \\
\hline $\mathbf{D}_{50}$ & $\begin{array}{l}\text { Diameter through which } 50 \% \text { of the total } \\
\text { soil mass is passing }(\mathrm{mm})\end{array}$ \\
\hline $\mathbf{D}_{60}$ & $\begin{array}{l}\text { Diameter through which } 60 \% \text { of the total } \\
\text { soil mass is passing }(\mathrm{mm})\end{array}$ \\
\hline $\mathbf{D}_{90}$ & $\begin{array}{l}\text { Diameter through which } 90 \% \text { of the total } \\
\text { soil mass is passing }(\mathrm{mm})\end{array}$ \\
\hline e & The natural soil void ratio \\
\hline $\mathrm{Fr}$ & Froude number \\
\hline GS & Specific Gravity \\
\hline $\mathbf{H}$ & Depth of water $(m)$ \\
\hline $\mathbf{n}$ & The natural soil Porosity \\
\hline $\mathbf{Q}$ & Discharge $\left(\mathrm{m}^{3} / \mathrm{sec}\right)$ \\
\hline $\mathbf{R}$ & Hydraulic radius $(m)$ \\
\hline $\operatorname{Re}$ & Reynolds number \\
\hline $\mathbf{S}$ & Longitudinal slope \\
\hline SM & Silica Modulus \\
\hline SP & Poorly graded sand \\
\hline $\mathbf{V}$ & Velocity of water $(\mathrm{m} / \mathrm{sec})$ \\
\hline W & Width of canal $(m)$ \\
\hline$W_{110}{ }^{\circ}$ & Weight of sample at temperature of $110^{\circ} \mathrm{C}$ \\
\hline$W_{45}{ }^{\circ}$ & Weight of sample at temperature of $45^{\circ} \mathrm{C}$ \\
\hline $\mathrm{We}$ & Weber number \\
\hline$x$ & Maximum scouring of canal in $\mathrm{cm}$ \\
\hline $\boldsymbol{Y}$ & time in year \\
\hline$\chi$ & Gypsum content $(\%)$ \\
\hline$\tilde{C c}$ & Coefficient of gradation \\
\hline $\mathrm{Cu}$ & Uniformity coefficient \\
\hline$\gamma_{\max }$ & Maximum unit weight $\left(\mathrm{kn} / \mathrm{m}^{3}\right)$ \\
\hline$\mu m$ & Micrometer \\
\hline
\end{tabular}

\section{Abbreviations}

\section{Symbol Description}

ASTM American Society for Testing and Materials
LSF Lime Saturation Factor

USCS Unified Soil Classification System

Z.A.V.L. Zero Air Voids Line

\section{Acknowledgements}

The authors gratefully acknowledge the department of water resources engineering / University of Baghdad for their help and the study support. We are also grateful to the laboratories of the Iraqi Geological Survey/Ministry of Industry, and also Technical Institute /Shatra for performing most tests. 


\section{Appendix A}

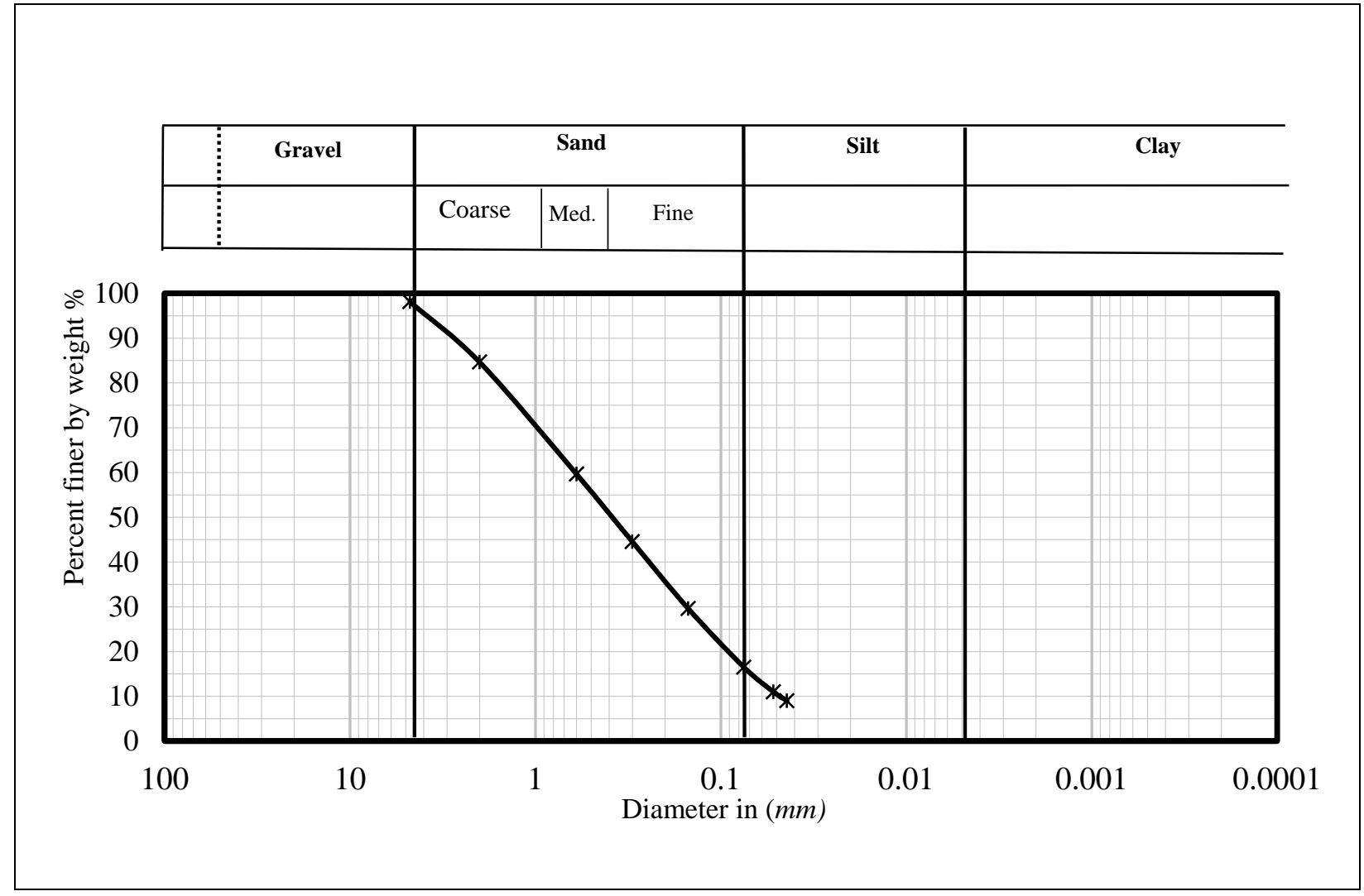

Figure A-1: Standard sieve analysis test of the natural soil

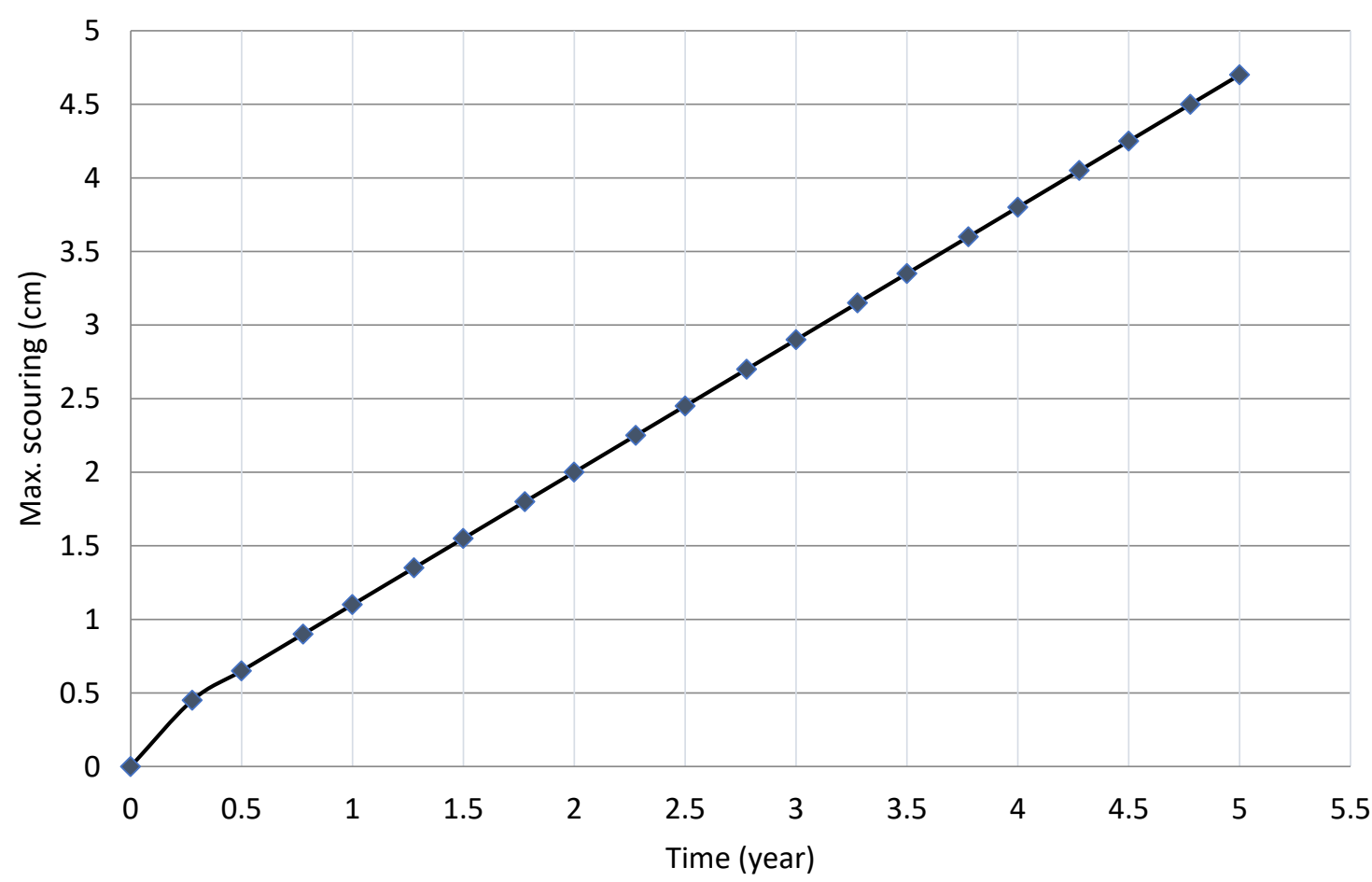

Figure A-2: The relation between maximum scouring of lining material and time in rationing system case 


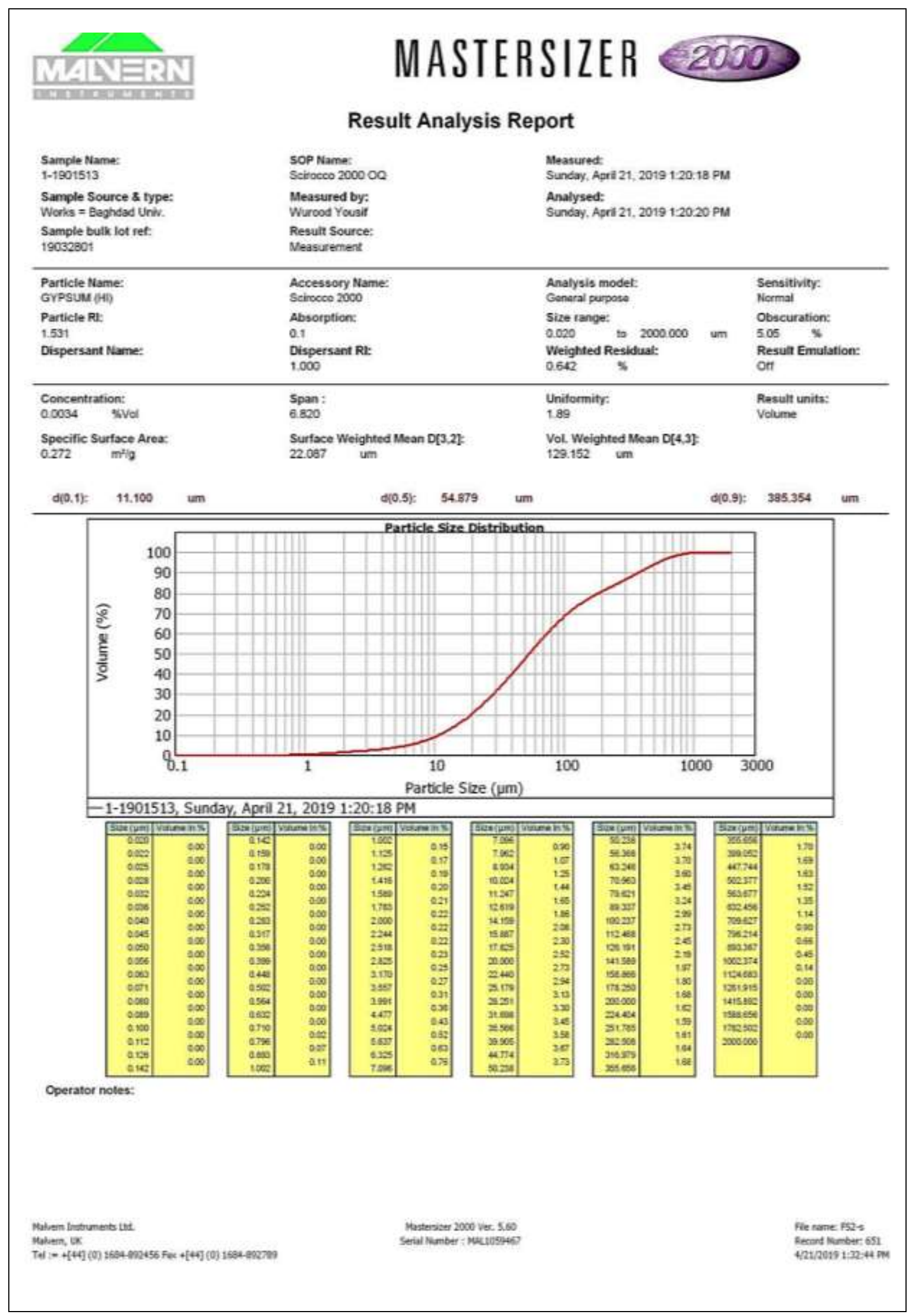

Figure A-3: The particle size absorptive for first cycle of rationing 


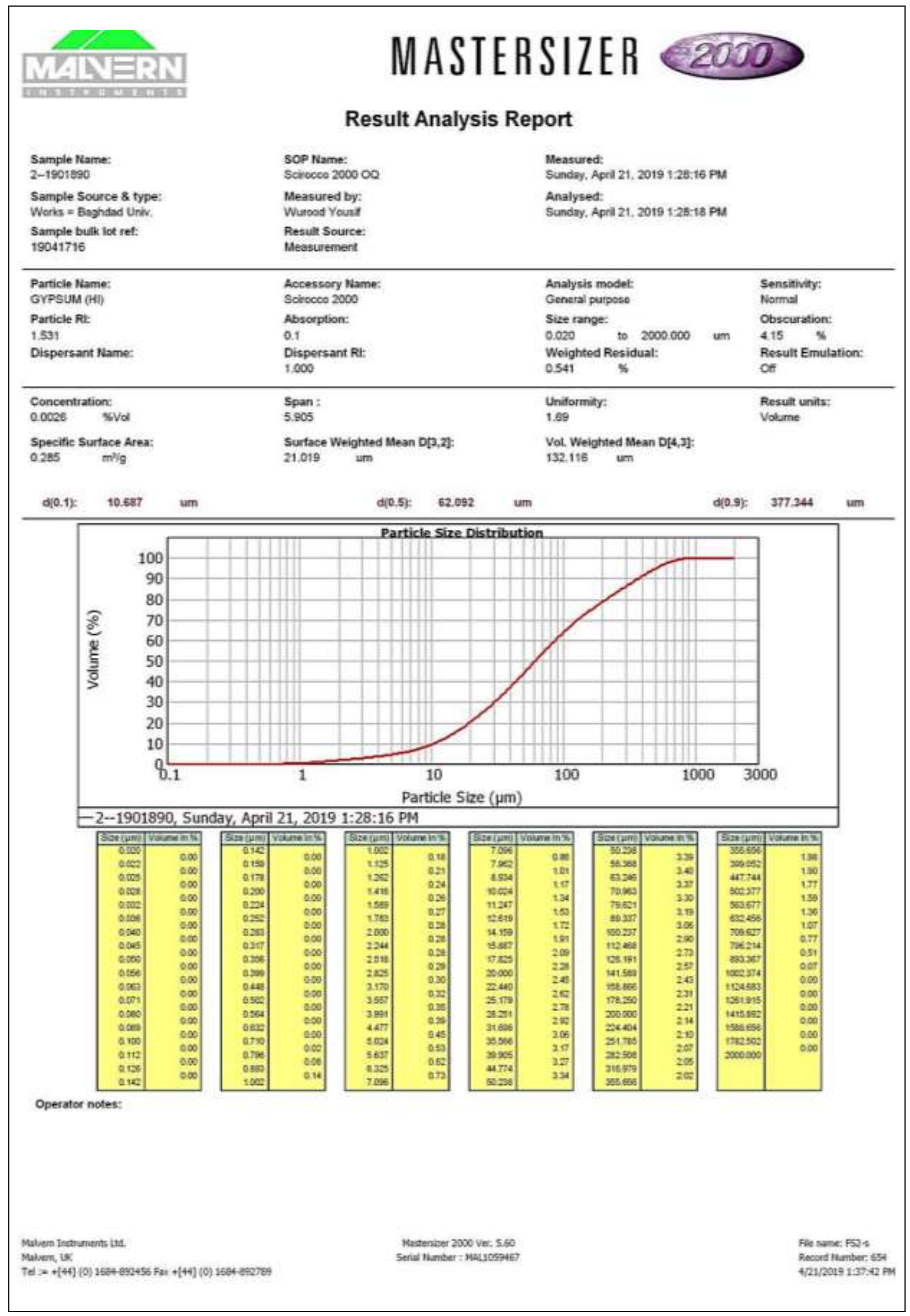

Figure A-4: The particle size absorptive for second cycle of rationing 


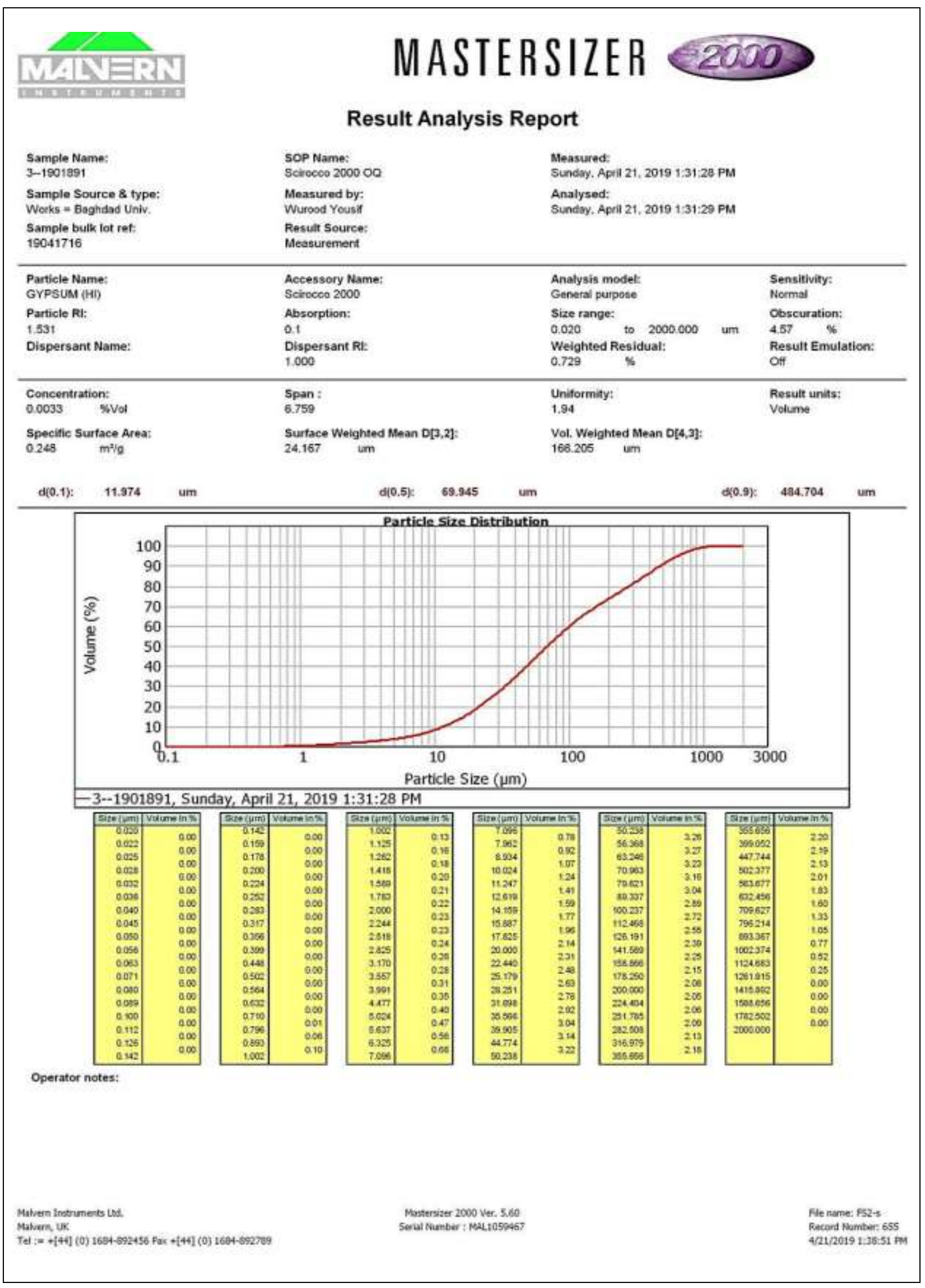

Figure A-5: The particle size absorptive for third cycle of rationing 


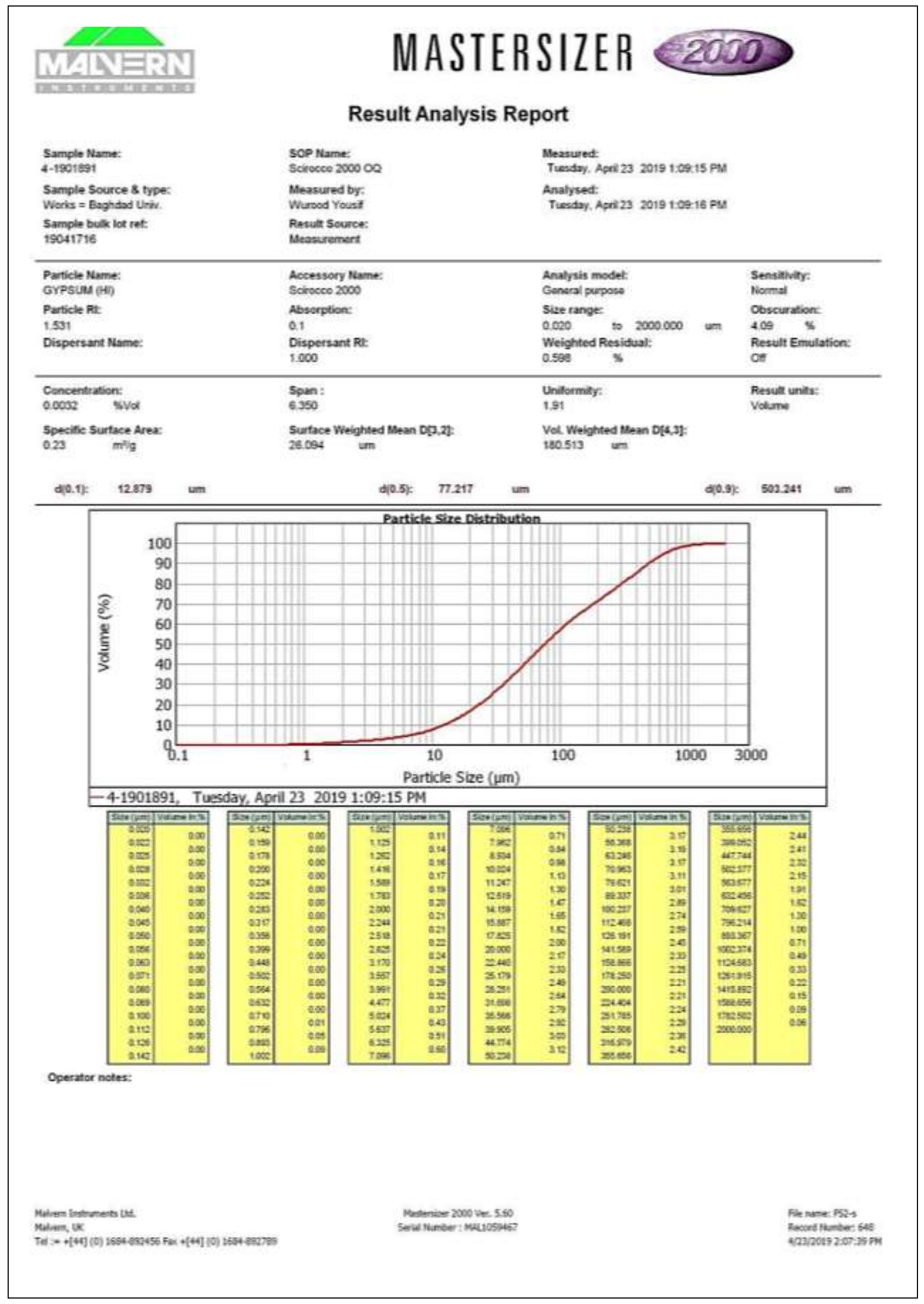

Figure A-6: The particle size absorptive for fourth cycle of rationing 


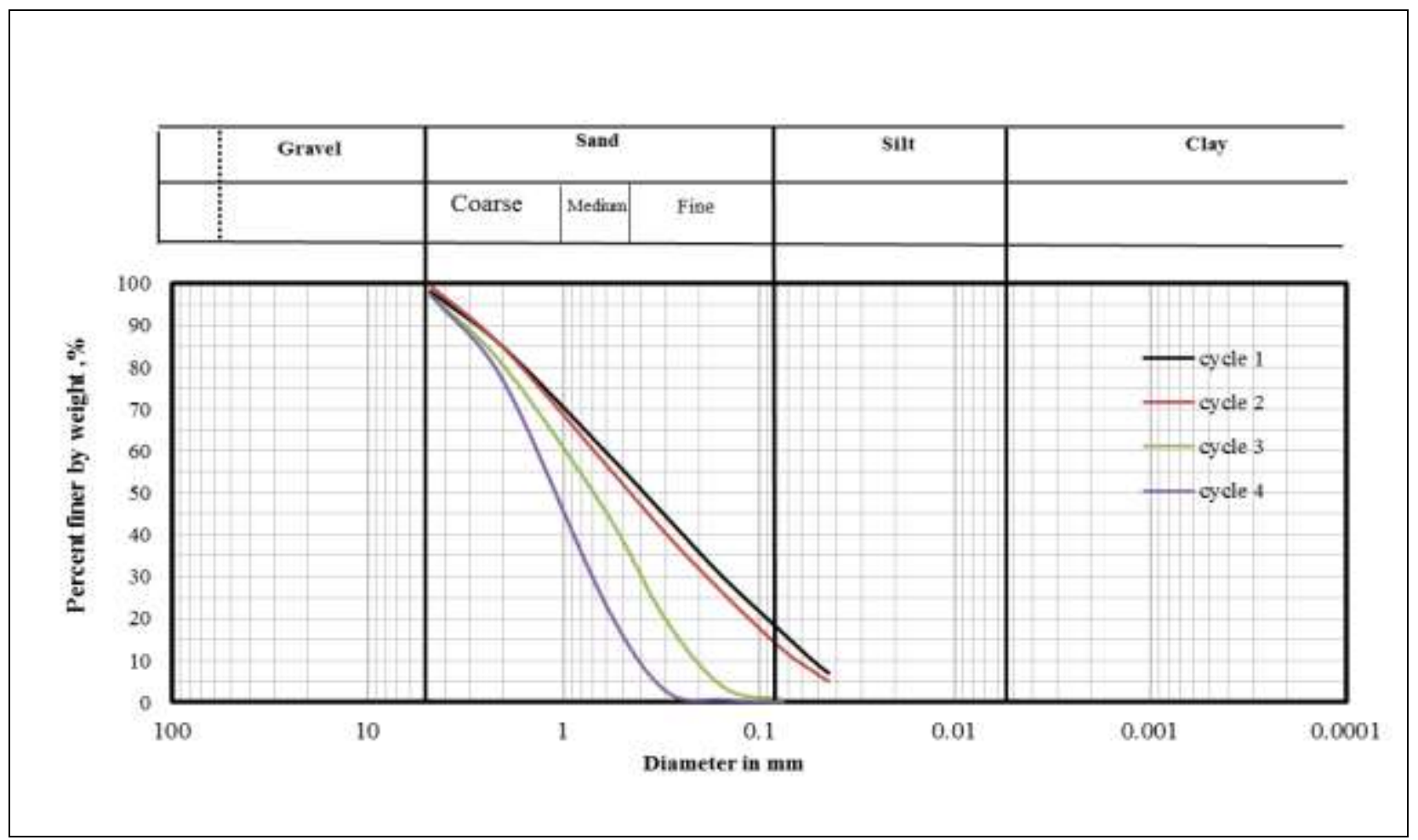

Figure A-7: Effect of the rationing system on particle size distribution of the soil

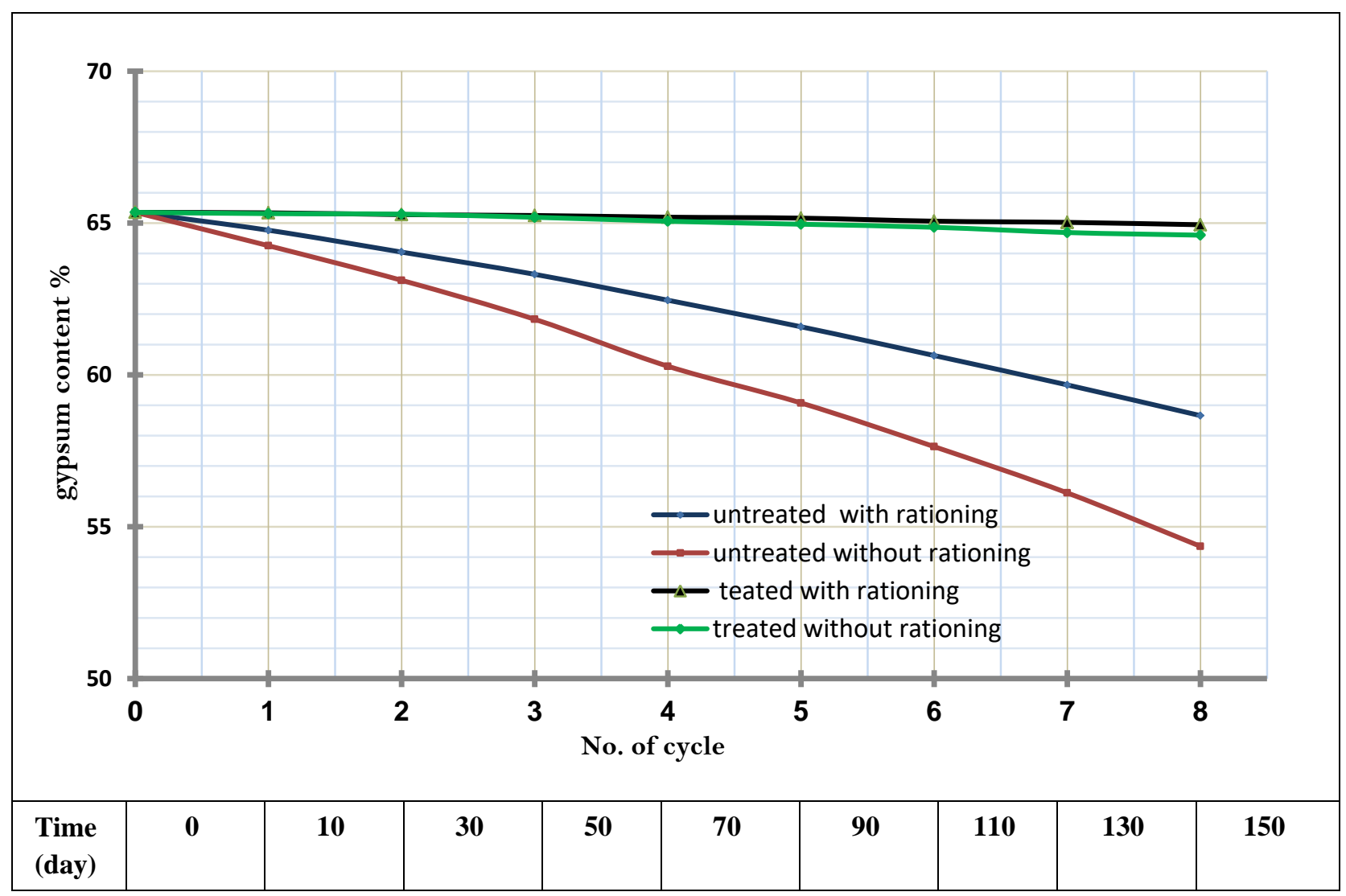

Figure A-8: Effect of rationing cycles on the gypsum content of gypsoeus canals 


\section{References}

[1] Ahmad, Fauziah, M. A. Said, and Lamyaa Najah. "Effect of leaching and gypsum content on properties of gypseous soil "IJSRP, vol. 2, no. 9 , p. 1-5, 2012.

[2] Al-Hadidi, Maysam Th, and Zeina Hamed Nasir AL-Maamori. "Improvement of Earth Canals Constructed on Gypseous Soil by Soil Cement Mixture" Journal of Engineering, vol. 25, no. 3, p. 23-37,2019.

[3] Al-Mufty, A. A., and I. H. Nashat. "Gypsum content determination in gypseous soils and rocks" Proceedings of the 3th Jordanian international mining conference, Amman, vol. 2, 2000 .

[4] Al-Musawi, Q. S. K. "Effect of leaching on engineering properties of High Gypseous subgrade soil" Master's thesis, Dep. of Highway and Transportation Engineering, University of Al-Mustansiriya, 2005.

[5] Al-Zubaydi, Abdulrahman H., Moafaq A. AlAtalla, and Ibrahaim M. Al-Kiki. "Long term strength and durability of clayey soil stabilized with lime" Engineering \& Technology Journal, vol. 29, no. 4, p. 725-735, 2011.

[6] ASTM D422 Standers, "Soil and Rock (I)" vol 04.08, 2002.

[7] ASTM, D698 "Standard Test Methods for Laboratory Compaction Characteristics of Soil Using Standard Effort (12,400 ft-lbf/ft 3 (600 $\mathrm{kN}-\mathrm{m} / \mathrm{m} 3)) ", 2003$.

[8] British Standard Institution BS 1377, Method of Testing Soils for Civil Engineering Purposes, London, 1975.
[9] Fookes, P. G. "Middle East-inherent ground problems" Quarterly Journal of Engineering Geology and Hydrogeology, vol. 11, no. 1, p. 33-49, 1987.

[10] Jafarzadeh, A. A., and J. A. Zinck. "Worldwide distribution and sustainable management of soils with gypsum" Proceedings of the International Symposium on Desertification, p. 362-368, 2002.

[11] Namdar, Abdoullah, and G. S. Gopalakrishna. "Analysis of Mixed Soil Model Characteristics" Modern Applied Science, vol. 3, no. 5, p. 199-203, 2009.

[12] Razouki, Sabah S., Dina K. Kuttah, and Maha H. Abood."Compaction and design of gypsiferous fill for hot desert road pavements" Proceedings of the Institution of Civil Engineers-Construction Materials, vol. 164, no. 1, p. 3-11, 2010.

[13] Razouki, Sabah Said, and Bushra M. Salem. "Impact of soaking-drying cycles on gypsum sand roadbed soil." Transportation Geotechnics, vol. 2, p. 78-85, 2015.

[14] Shu, Xia, et al. "Mastersizer 2000 laser particle size analyzer and its applications $[\mathrm{J}]$ " Journal of Hefei University of Technology (Natural Science), vol. 2, 2007.

[15] Standard Specification for Cement "specifications Iraqi standards " Iraqi Ministry of Planning, no. 5, 1984.

[16] Standard, British. "1377 (1990) Methods of test for soils for civil engineering purposes" British Standards Institution, London, 2004. 


\section{تأثير المراشنة على خواص القنوات الجبسية المعالجة بالاسمنت}

وسام سامي الجاسم 1*، ميسم ثامر الحديدي2

1 قسم هندسة الموارد المائية ، جامعة بغداد، ،بغداد،العراق، wissamiraq2000@yahoo.com

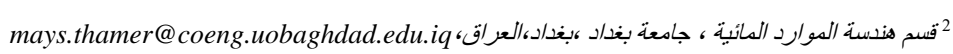

"الباحث المثل: : وسام سامي الجاسم، wissamiraq2000@yahoo.com "

نر في: 30 ايلول 2020

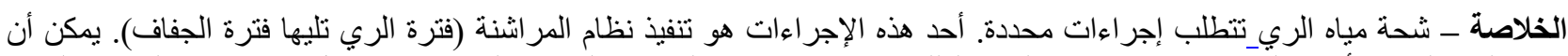

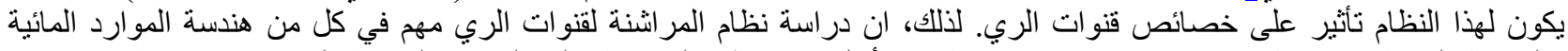

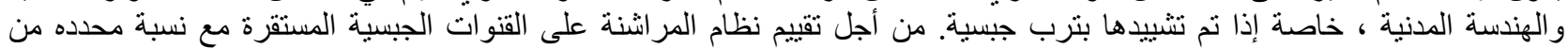

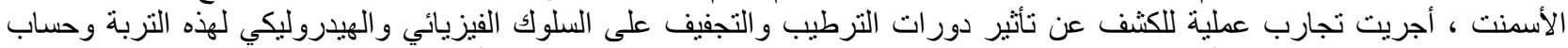

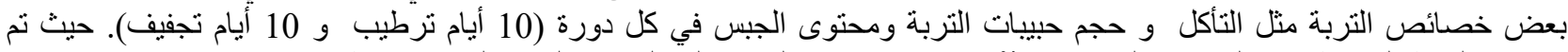

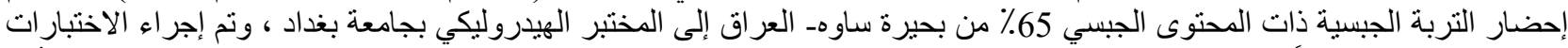

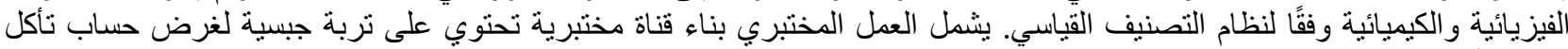

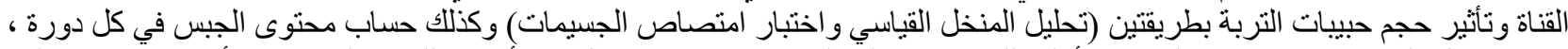

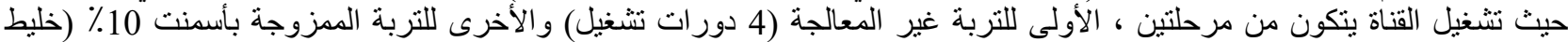

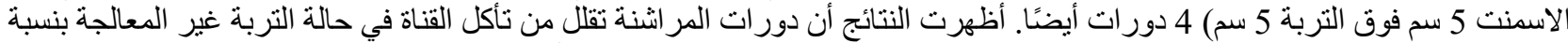

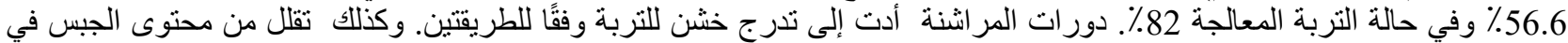

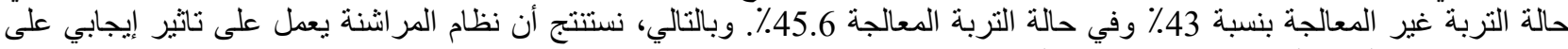
بعض خصائص التربة الجبسية وبطانة قنوات الرية الري.

الكلمات الرئيسية ـ نظام المر اشنة ، الترطيب و التجفيف ، التربة الجبسية ، قنوات الري ، التأكل. 